\title{
Economic costs of biological invasions in the United States
}

\author{
Jean E. Fantle-Lepczyk ${ }^{\mathrm{a}, *, 1}$, Phillip J. Haubrock ${ }^{\mathrm{b}, c, 1}$, Andrew M. Kramer ${ }^{\mathrm{d}, 1}$, Ross N. Cuthbert ${ }^{\mathrm{e}, \mathrm{f}, 1}$, Anna J. Turbelin ${ }^{\mathrm{g}}$, \\ Robert Crystal-Ornelas ${ }^{\mathrm{h}}$, Christophe Diagne ${ }^{\mathrm{g}}$, Franck Courchamp ${ }^{\mathrm{g}}$ \\ a Auburn University, School of Forestry E Wildlife Sciences, 602 Duncan Dr, Auburn, AL 36849, USA \\ b Senckenberg Research Institute and Natural History Museum Frankfurt, Department of River Ecology and Conservation, Gelnhausen, Germany

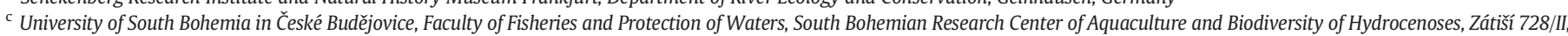 \\ 38925 Vodñany, Czech Republic \\ d University of South Florida, Department of Integrative Biology, Tampa, FL 33610, USA \\ e GEOMAR Helmholtz-Zentrum für Ozeanforschung Kiel, Düsternbrooker Weg 20, 24105 Kiel, Germany \\ f School of Biological Sciences, Queen's University Belfast, 19 Chlorine Gardens, BT9 5DL Belfast, Northern Ireland, United Kingdom \\ ${ }^{g}$ Université Paris-Saclay, CNRS, AgroParisTech, Ecologie Systématique Evolution, 91405 Orsay, France \\ ${ }^{\mathrm{h}}$ Ecology, Evolution, and Natural Resources, Rutgers University, 14 College Farm Road, New Brunswick, NJ 08901, USA
}

\section{H I G H L I G H T S}

- From 1960 to 2020 reported costs of US biological invasions were at least $\$ 1.22$ tril.

- Annual invasion costs increased from $\$ 2$ bil in 1960-69 to \$21 bil in 2010-20.

- Most costs were damages ( $\$ 896$ bil), with lower management investments (\$47 bil).

- Agriculture sector ( $\$ 510$ bil) and terrestrial habitat ( $\$ 644$ bil) were impacted most.

- Knowledge gaps in reporting make these monetary costs severely underestimated.

\section{A R T I C L E I N F O}

\section{Article history:}

Received 15 July 2021

Received in revised form 25 October 2021

Accepted 26 October 2021

Available online 30 October 2021

Editor: Damià Barceló

\section{Keywords:}

InvaCost

Invasive alien species

Nonindigenous species

Non-native species

Socioeconomic damages

\section{G R A P H I C A L A B S T R A C}

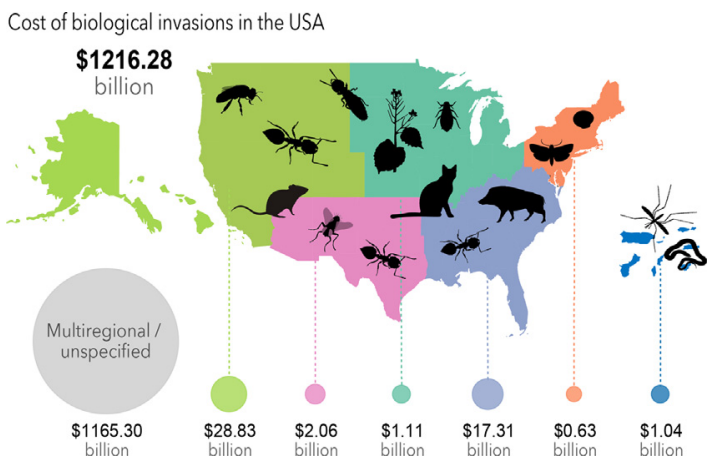

\begin{abstract}
A B S T R A C T
The United States has thousands of invasive species, representing a sizable, but unknown burden to the national economy. Given the potential economic repercussions of invasive species, quantifying these costs is of paramount importance both for national economies and invasion management. Here, we used a novel global database of invasion costs (InvaCost) to quantify the overall costs of invasive species in the United States across spatiotemporal, taxonomic, and socioeconomic scales. From 1960 to 2020, reported invasion costs totaled $\$ 4.52$ trillion (USD 2017). Considering only observed, highly reliable costs, this total cost reached $\$ 1.22$ trillion with an average annual cost of $\$ 19.94$ billion/year. These costs increased from $\$ 2.00$ billion annually between 1960 and 1969 to $\$ 21.08$ billion annually between 2010 and 2020. Most costs (73\%) were related to resource damages and losses ( $\$ 896.22$ billion), as opposed to management expenditures ( $\$ 46.54$ billion). Moreover, the majority of costs were reported from invaders from terrestrial habitats ( $\$ 643.51$ billion, $53 \%$ ) and agriculture was the most impacted sector ( $\$ 509.55$ billion). From a taxonomic perspective, mammals ( $\$ 234.71$ billion) and insects ( $\$ 126.42$ billion) were the taxonomic groups responsible for the greatest costs. Considering the
\end{abstract}

\footnotetext{
* Corresponding author.

E-mail addresses: fantle@auburn.edu (J.E. Fantle-Lepczyk), Phillip.haubrock@senckenberg.de (P.J. Haubrock), amkramer@usf.edu (A.M. Kramer), anna.turbelin@universite-paris-saclay.fr (A.J. Turbelin), christophe.diagne@universite-paris-saclay.fr (C. Diagne), franck.courchamp@cnrs.fr (F. Courchamp).

${ }^{1}$ The contributions from these authors are equivalent.
} 
apparent rising costs of invasions, coupled with increasing numbers of invasive species and the current lack of cost information for most known invaders, our findings provide critical information for policymakers and managers.

(C) 2021 The Authors. Published by Elsevier B.V. This is an open access article under the CC BY-NC-ND license (http:// creativecommons.org/licenses/by-nc-nd/4.0/).

\section{Introduction}

Biological invasions damage natural systems worldwide (Pyšek et al., 2020; Simberloff, 2015). Non-native invasive species, organisms introduced beyond their natural range by human activity, can cause negative ecological and economic impacts as they spread through the novel environment. These species degrade ecosystem services (e.g., Walsh et al., 2016), disrupt natural communities (e.g., Dorcas et al., 2012), and significantly threaten or endanger native species (Blackburn et al., 2019). These damages are exemplified by a number of species that individually have had massive, widely apparent impacts. In the United States, well-publicized examples include zebra and quagga mussels (Dreissena polymorpha and D. bugensis, respectively), which have altered biophysical characteristics in the Great Lakes and clogged water intakes (e.g., Miehls et al., 2009), Burmese pythons (Python bivittatus), brown tree snakes (Boiga irregularis), and rats (Rattus sp.) which have reduced or extirpated native birds, reptiles, and mammals (Dorcas et al., 2012; Wiles et al., 2003; Doherty et al., 2016), salt cedar (Tamarix spp.) which has disrupted surface and groundwater in the western United States (Zavaleta, 2000), the emerald ash borer (Agrilus planipennis) which has reshaped tree communities, particularly in urban areas (Kovacs et al., 2010), and the chytrid fungal disease (Batrachochytrium dendrobatidis) which has severely reduced many amphibian populations (Dueñas et al., 2018).

The wide-reaching ecological impacts of individual invasive species in the United States have been correlated with marked economic impacts. For instance, zebra mussels cost businesses and communities over $\$ 5$ billion in the first 10 years after invasion alone (Boelman et al., 1997) and emerald ash borers have been estimated to cost $\$ 10$ billion over a decade in lost forest resources (Kovacs et al., 2010). Collectively, invaders threaten United States agriculture (Paini et al., 2016), damage critical infrastructure (e.g., water treatment facilities, electrical power; Boelman et al., 1997, Connelly et al., 2007), and substantially lower the value of property and other personal assets (Johnson and Meder, 2013). For example, rush skeletonweed (Chondrilla juncea) caused an estimated $\$ 62$ million annual loss to wheat, potato, legume, and hay crops in Washington state alone (Mefford et al., 2017). Further, rapidly spreading invasive insects, such as the gypsy moth (Lymantria dispar) and hemlock wooly adelgid (Adelges tsugae) threaten forest resources and human wellbeing (Mcmanus and Csóka, 2007; Aukema et al., 2011), while expanding invasive mosquito populations vector pathogens that cause massive human health costs (Shepard et al., 2011).

Given the great diversity in types of economic impacts from invasive taxa in the United States, the actual aggregate costs remain highly uncertain. This uncertainty is mainly due to the lack of synthesis of costs reported across spatiotemporal, taxonomic, and socioeconomic scales. This can result in highly variable cost estimates, sometimes differing by orders of magnitude. For instance, feral cats (Felis catus) cause great damage to native species, and multiple attempts have been made to value the effects of their depredations. However, these attempts vary widely, ranging from $\$ 30 /$ bird (Pimentel et al., 2005) to $\$ 1500 /$ bird (Lohr et al., 2013). When multiplied by the hundreds of millions of birds killed by cats every year, the discrepancy between estimates is vast. In an example of scale mismatch, Anderson et al. (Anderson et al., 2016) quantified agricultural damage costs of wild pigs (Sus scrofa) across 11 United States based on empirical observations, while Sytsma and Rouhe (2007) extrapolated control costs of pigs within a single state in a different decade. Overall, the disparate nature of cost estimates, combined with the lack of centralized systems that denote attributes such as method reliability, complicates cost comparisons across contexts. Ultimately, the thousands of invasive species recorded in the United States represent a sizable burden to the country's economy, but the extent of this burden is unknown.

While economic impacts of a few individual invasive species have been estimated across the entire United States (e.g., Martin and Blossey, 2013), there are no current, comprehensive estimates of total costs. The most recent estimate of gross economic costs for the United States was $\$ 120$ billion per year in 2005 (Pimentel et al., 2005), but this was criticized for methodological shortcomings, such as extrapolations from unclear baselines and a lack of spatiotemporal granularity (Hoffmann and Broadhurst, 2016, Cuthbert et al., 2020). Extrapolated and uncertain cost estimates are particularly problematic in the context of the United States economy, given its size and importance within the global economy. Indeed, the United States has the largest economy in the world, with a 2019 GDP of \$21 trillion (World Bank, 2020) and is amongst the top three global importers/exporters, including trade agreements with 75 countries worldwide (Office of the United States Trade Representative, 2020). With the increasingly open economy, global trade volume has risen markedly over the past 50 years. Costs due to invaders are thus likely increasing across the United States (as they are globally, Diagne et al., 2021), as higher trade volumes introduce a suite of new species, while climate change facilitates the establishment and spread of already introduced species (Seebens et al., 2017, 2018, Lockwood et al., 2019). Such increases, coupled with the current lack of reliable cost appraisals, inhibit effective decision making by policy makers involved in prevention and management of biological invasions in the United States, as well as hamper effective communication of the problem to the general public. While not all impacts of invasive species are economically quantifiable, robust estimates of their economic impacts can be a convincing way of communicating the scale of the problem to a diverse audience. Thus, a synthesized, comprehensive record of invasion costs is urgently needed to highlight the necessity of invasive species management to both decision makers and the public.

The InvaCost database (Diagne et al., 2020a) seeks to address this lack of robust cost information by presenting a comprehensive global database of reported costs of invasive species. It links costs from a variety of source documents with standardized taxonomic, sectorial, regional, and temporal descriptors. We used this database, as well as complementary cost sources, to synthesize and analyze currently available information on costs of invasions in the United States economy. Specifically, our aim was to quantify how these costs are distributed by region, cost type, environment, societal sector, and taxonomic group, as well as to calculate annual and cumulative costs of invasive species from 1960 to present. Quantifying these values provides a vital step towards understanding the true socioeconomic impact of invasive species across the United States and implementing efficient and evidence-based management actions.

\section{Methods}

\subsection{InvaCost database}

To estimate the cost invasive species have on the United States economy, we extracted recorded costs for the United States from the InvaCost v3 database, which consists of 9823 entries from 1605 studies 
of reported economic costs of invasive species (Diagne et al., 2020a, https://doi.org/10.6084/m9.figshare.12668570). The data included in the InvaCost database were retrieved via a structured review of publications found in the Web of Science platform, Google Scholar, the Google search engine and through consultation with invasive species experts (Diagne et al., 2020a), along with analogous searches conducted in more than 10 non-English languages (e.g., French, Spanish, Chinese, and Japanese; Angulo et al., 2021; https://doi.org/10.6084/m9.figshare. 12928136). Individual cost records were converted to USD 2017.

To derive the costs of invasive species on the United States economy, we filtered the database to include country "USA", thereby excluding costs shared between the United States and other countries (e.g., Canada). We examined the resulting database subset for doublecounted and redundant data. All such redundancies were removed from the database or edited to remove overlapping dating of costs, as appropriate. All corrected costs were forwarded to updates@invacost.fr as requested by InvaCost managers to update the main database. The resulting dataset contained 1534 entries specific to the United States, derived from 416 studies (Dataset S1), representing available data for non-native species which have reported a monetary cost, irrespective of the year they were introduced to the novel range.

We added an additional descriptor to the database that classified the entries by region: Northeast, Southeast, Midwest, Southwest, West, Outlying territories (Puerto Rico, Guam, Commonwealth of the Northern Mariana Islands, minor atolls), and multiregional/unspecified. We aimed to provide the most robust, yet conservative estimates of the costs of invasions in the US. For this purpose, we analyzed only highly reliable and observed costs, using the InvaCost database method reliability and implementation type categorizations. Assessing methods for estimating costs across hundreds of heterogeneous studies reporting on diverse taxonomic groups, habitats, and economic sectors, makes a clear dichotomy between high and low reliability very challenging (Diagne et al., 2021). To maximize objectivity, the study used welldefined, consistent criteria to assess study reliability (see Diagne et al., 2020a for full details on these criteria). Highly reliable entries were those classified in the 'Method reliability' column as high, and include data from peer-reviewed, official, and repeatable materials, as opposed to low, non-verifiable or non-repeatable estimates. Observed costs were those classified in the 'Implementation' column as an observed, actually realized cost, as opposed to a potential cost, which is not currently accrued or realized. As a result, we excluded from analysis all entries that were not from peer-reviewed literature or official reports (e.g., government documents), or were otherwise not reproducible, as well as those that were extrapolated but not empirically observed (Diagne et al., 2020a). The resulting estimate, derived from the best available data, represents a robust summation of reported costs of invasive species in the United States, which is, in turn, a minimum estimate of actual costs, as many costs likely go unestimated and unreported.

In addition to overall invasion costs, we also analyzed costs by several key components, both across the entire United States and by region. These include the variables of cost type, environment, impacted sector, and taxa (see Table 1 for details and category definitions). Cost types were categorized into broad impact categories within the InvaCost database (Diagne et al., 2020a). For each variable, if the respective criteria were unspecified or covered multiple categories, we gave it an aggregate category (mixed cost type, mixed environment, multisectoral, multitaxon).

\subsection{Costs over time}

We analyzed average annual costs and cumulative costs using yearly cost data output from the expandYearlyCosts function in the 'invacost' package in R v4.0.2 (R Core Team, 2020, Leroy et al., 2021). This function calculated annual costs (hereafter called annual cost entries) by dividing the total cost after conversion to USD 2017 by the number of years over which the total cost was incurred. We therefore calculated the
Table 1

Categories, definitions and classes of variables included in the InvaCost database. Definitions of categories and classes are from Diagne et al., 2020a.

\begin{tabular}{|c|c|c|}
\hline Category & Definition & Classes \\
\hline Region & $\begin{array}{l}\text { Area of the United States } \\
\text { in which cost occurred }\end{array}$ & $\begin{array}{l}\text { Midwest } \\
\text { Northeast } \\
\text { Southeast } \\
\text { Southwest } \\
\text { West } \\
\text { Outlying territories } \\
\text { Multi/unspecified }\end{array}$ \\
\hline $\begin{array}{l}\text { Method } \\
\text { reliability }\end{array}$ & $\begin{array}{l}\text { Assessment of the } \\
\text { methodological } \\
\text { approach used for cost } \\
\text { estimation }\end{array}$ & $\begin{array}{l}\text { High-data from officially assessed } \\
\text { materials or is documented and } \\
\text { repeatable } \\
\text { Low-data from gray materials or not } \\
\text { repeatable }\end{array}$ \\
\hline Implementation & $\begin{array}{l}\text { Referring to whether } \\
\text { the cost estimate was } \\
\text { actual or potential }\end{array}$ & $\begin{array}{l}\text { Observed-cost was actually or likely } \\
\text { realized } \\
\text { Potential-cost is expected to exist or } \\
\text { could exist in the future, but is not } \\
\text { currently verifiable }\end{array}$ \\
\hline Environment & $\begin{array}{l}\text { Origin of the species } \\
\text { causing the cost }\end{array}$ & $\begin{array}{l}\text { Aquatic-species that develop, reproduce } \\
\text { and forage completely within water } \\
\text { Semi-aquatic-species that utilize both } \\
\text { aquatic and terrestrial habitats for } \\
\text { e.g., development, reproduction, or } \\
\text { foraging. } \\
\text { Terrestrial-species that develop, } \\
\text { reproduce and forage completely on land } \\
\text { Mixed/unspecified-entries that span } \\
\text { multiple habitat types, or unspecified } \\
\text { ones. }\end{array}$ \\
\hline Cost type & Type of cost estimate & $\begin{array}{l}\text { Damage/loss-incurred by invasion } \\
\text { (i.e., costs for damage repair, resource } \\
\text { losses, medical care) } \\
\text { Management-comprising } \\
\text { control-related expenditure } \\
\text { (i.e., monitoring, prevention, control, } \\
\text { eradication, research, and administrative } \\
\text { costs) } \\
\text { Mixed-mixed damage/loss and } \\
\text { control costs or costs not clearly } \\
\text { distinguished }\end{array}$ \\
\hline Sector & $\begin{array}{l}\text { The activity, societal or } \\
\text { market sector that was } \\
\text { impacted by the cost }\end{array}$ & $\begin{array}{l}\text { Agriculture-food and useful products } \\
\text { produced by human activity using } \\
\text { plant and animal resources } \\
\text { Authorities and stakeholders- } \\
\text { governmental services and } \\
\text { organizations that allocate resources } \\
\text { for control of biological invasions } \\
\text { Environment-impacts on natural } \\
\text { resources, ecological processes or } \\
\text { ecosystems services } \\
\text { Fisheries-fish-based activities and } \\
\text { services } \\
\text { Forestry-forest-based activities and } \\
\text { services } \\
\text { Health-items directly or indirectly } \\
\text { related to the sanitary state of people } \\
\text { Public and social welfare-activities, } \\
\text { goods, and services contributing to } \\
\text { human well-being and safety } \\
\text { Multi/unspecified-from more than } \\
\text { one sector or sector is not specified }\end{array}$ \\
\hline
\end{tabular}

cost over time for an individual entry by determining when the cost first and last occurred for every entry in our database, using information from the document reporting the cost. For example, a total cost of $\$ 100,000$ reported by the original source as accruing over ten years would correspond to ten entries of $\$ 10,000$ each. Specifically, we derived the total cumulative cost of invasions over time by calculating the probable duration time of each cost entry (duration time $=$ probable end year of cost - probable first year of cost). When no starting year was indicated, we conservatively used the reference's publication year. In some cases, probable ending year information was missing for potentially ongoing costs, which are costs likely to be repeated over years 
(contrary to one-time costs occurring only once). When no period of impact was specified, we counted only a single year (though costs might have repeated over many years, even to the present), making these estimates conservative, but also contributing to high variance between years.

We further used the costs over time to quantify the average annual costs of invasives in the United States between 1960 and 2020, and the average annual cost by decade over this period. Given the known time lags between the actual occurrence of costs and their reporting in the literature, we used quantiles from the time difference between when reported costs occurred and when they were published to apply time lag adjustments $(25 \%=1$ year, $50 \%=4$ years, $75 \%=11$ years; Leroy et al., 2021, Diagne et al., 2021). We thus applied a correction to account for incomplete years, whereby, based on the above quantiles, costs after 2016 were removed from analysis as our model predicted $<50 \%$ of expected costs have been reported. We then fit the temporal dynamics of reported costs with generalized additive models (GAM), multivariate adaptive regression splines (MARS), robust regression to reduce the influence of outliers, least squares regression using the sandwich variance adjustment, and quantile regression (quantiles $0.1,0.5$, 0.9 ) all as implemented by default in the costTrendOverTime function from the 'invacost' package (Leroy et al., 2021). Model performance was assessed with root mean square error (RMSE; lower values indicate a better fit), with the understanding that not all models are equally appropriate for the data subset, which necessitates some qualitative rationale in model choice (Leroy et al., 2021). In evaluating models, we made the qualitative assumption that costs due to invaders are most likely stable or increasing because invasion rates worldwide show no sign of saturation (Seebens et al., 2017), and thus economic impacts from invasive species are unlikely to be decreasing. At the same time, both awareness and reporting of economic impacts of non-native invaders are rising (Diagne et al., 2021), making it even more likely that any recent declines in costs would be due to time lags in reporting, rather than actual decreases in costs.

\section{Results}

\subsection{National and regional}

Reported invasion costs across the United States from 1960 to 2020 totaled $\$ 1.22$ trillion ( $n=1750$ annual cost entries) when conservatively considering only observed, highly reliable cost estimates. When we considered all data, reported costs reached $\$ 4.51$ trillion $(n=$ 4790 ). Of these, $52 \%$ ( $\$ 2.36$ trillion; $n=2645$ ) were observed and $48 \%$ ( $\$ 2.16$ trillion; $n=2145$ ) were potential costs. Most costs (62\%) originated from highly reliable sources ( $\$ 2.78$ trillion; $n=3433$ ), while $\$ 1.73$ trillion $(n=1357 ; 38 \%)$ were classified as low reliability. For the purposes of this study, we opted to be conservative and only focused on observed, highly reliable costs for further analysis.

Across regions within the United States, invasion costs differed considerably (Fig. 1; Table S1). The West had the highest regionally defined costs ( $\$ 28.84$ billion, $n=747$ ) with over half of the estimated regionspecific costs (58\%), followed by the Southeast ( $\$ 17.31$ billion; $n=$ 211 ), the Southwest ( $\$ 2.06$ billion; $n=26$ ), the Midwest ( $\$ 1.11$ billion; $n=59$ ), the outlying territories ( $\$ 1.04$; billion; $n=94)$, and lastly the Northeast ( $\$ 632.30$ million; $n=77$ ). However, the vast majority of costs ( $\$ 1.17$ trillion; $n=536$ ) were from multiple or unspecified regions.

\subsection{Cost types and environments}

Over two-thirds (73\%) of reported costs (see Table 1 for cost type definitions) across the United States were related to resource damages and losses ( $\$ 896.22$ billion; $n=647$ ), while management costs were $\$ 46.54$ billion (4\%; $n=718$ ). The remaining 23\% ( $\$ 273.52$ million; $n=385$ ) were mixed or unspecified costs (Fig. 2). Damage costs were also highest in most regions except for the Southwest, where mixed costs dominated (Fig. 2, Table S2). The fraction of reported costs arising from management was highly variable, ranging from as high as $33 \%$ in the outlying territories to $2 \%$ in the Southeast.
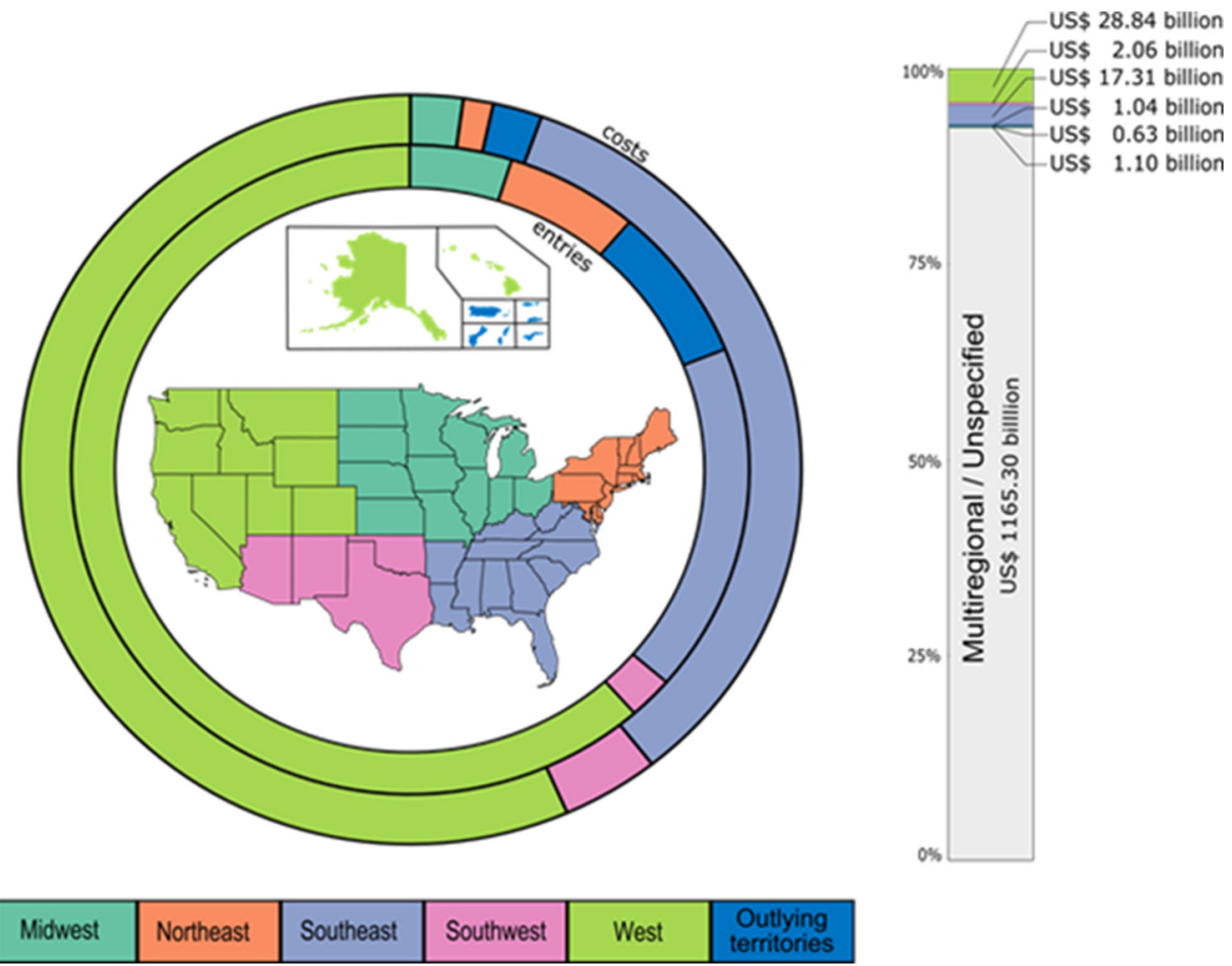

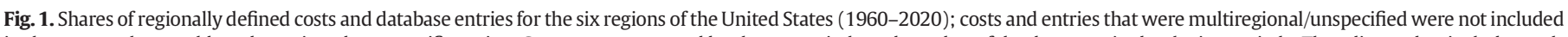

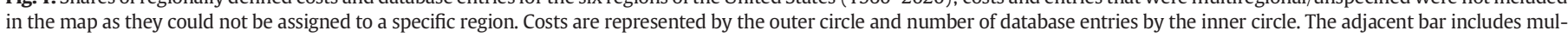
tiregional and unspecified region estimates. 


\section{Type of cost Environment}
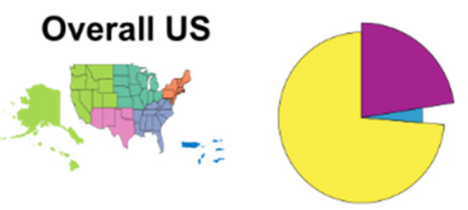

Midwest

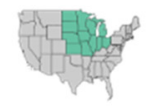

Northeast
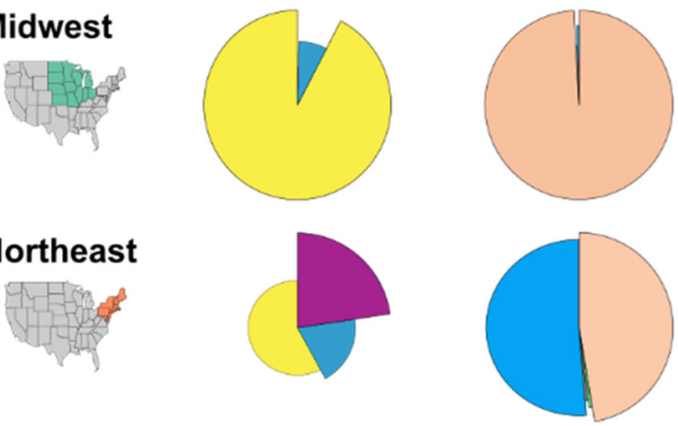

Southeast
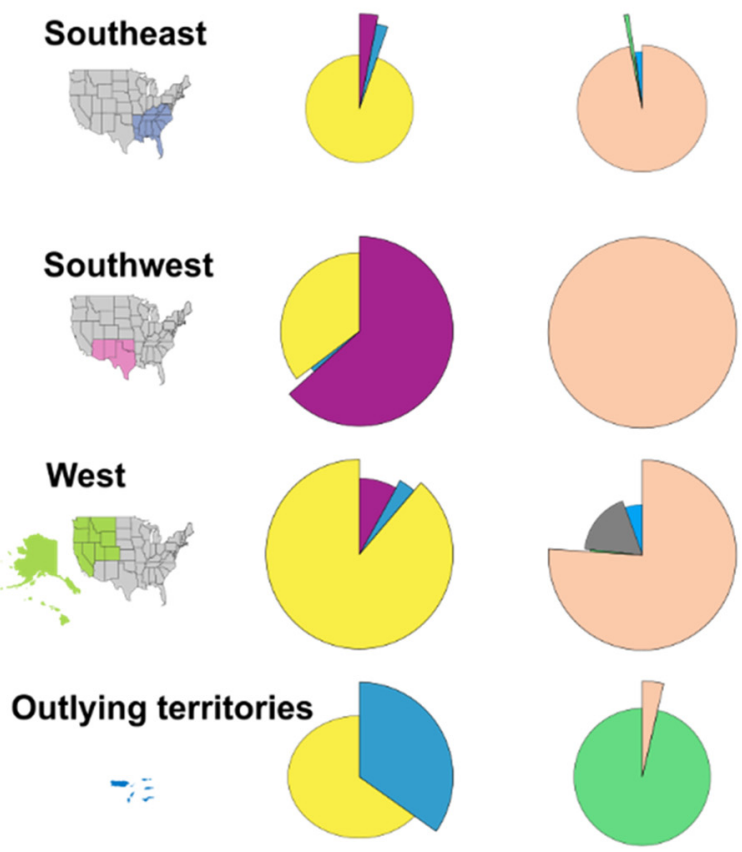

\section{Multiregional/ unspecified}
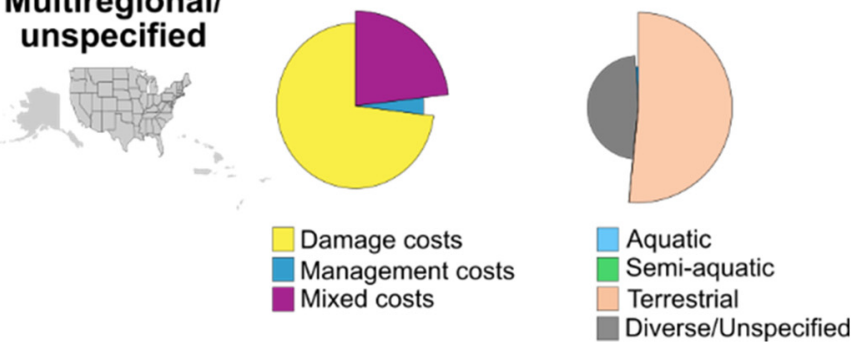

Fig. 2. Distribution of cost types and impacted environments across United States regions (1960-2020). The shares of each cost or environment type are scaled according to their respective number of entries in the database. Radius length represents the number of entries and arcs show the proportion of costs.

With regard to environment types (see Table 1 for definitions of environment types) across the entire United States (Fig. 2), invaders from terrestrial environments ( $\$ 643.51$ billion; $n=1156$; $53 \%$ ) caused the majority of reported costs, followed to a smaller degree by those from aquatic environments ( $\$ 13.45$ billion; $n=189 ; 1 \%$ ), and semi-aquatic environments ( $\$ 1.57$ billion; $n=193 ;<1 \%$ ). Entries from mixed or unspecified environments contributed $\$ 557.75$ billion ( $n=212 ; 46 \%)$. This held true within individual regions, where terrestrial costs dominated in all regions except the Northeast and the outlying territories, followed by costs in aquatic and semi-aquatic environments (Fig. 2, Table S3).

\subsection{Sectors and taxa}

When activity sector (see Table 1 for sector definitions) was defined, agriculture was the most impacted ( $\$ 509.55$ billion, $n=259$ ), followed by environmental ( $\$ 102.59$ billion; $n=108$ ), forestry ( $\$ 42.61$ billion; $n=20$ ), public and social welfare sectors ( $\$ 40.74$ billion, $n=166$ ), and authorities-stakeholders ( $\$ 37.11$ billion; $n=839$ ). Fewer costs were reported for the health sector ( $\$ 19.49$ billion; $n=61$ ), while fisheries ( $\$ 40.12$ million; $n=7$ ) was the least impacted sector in our dataset. Distributions of costs within sectors differed considerably across regions. Of regionally specific costs, agriculture was the most impacted sector in the Midwest and West, public and social welfare in the Northeast and the Southwest, and forestry in the Southeast, while multisectoral costs dominated in the outlying territories (Fig. 3, Table S1).

Across the United States as a whole, mammals were the costliest class of invaders ( $\$ 234.71$ billion) with the agriculture, environment, and mixed sectors primarily bearing the costs (Fig. 3). Plants were the second costliest invaders at $\$ 190.45$ billion impacting primarily the agriculture sector. This was followed by insects ( $\$ 126.42$ billion), birds ( $\$ 5.39$ billion), mollusks ( $\$ 4.80$ billion), fungi ( $\$ 3.64$ billion), reptiles ( $\$ 1.21$ billion), fish ( $\$ 24.36$ million) and amphibians ( $\$ 9.29$ million), with decapods reporting the lowest group-specific costs at $\$ 1.89$ million. Other arthropods (excluding insects and decapods) contributed $\$ 3.77$ billion, other animals contributed $\$ 15.13$ billion, and other organisms, including microorganisms and undefined taxa $\$ 630.72$ billion. Where regions were identified, insects and plants continue to be within the top three costliest groups in all regions, except for the outlying territories where only insects are amongst the top three (Fig. 3). Within the United States regions, sectors impacted by invader classes also showed some key differences, with the Northeast showing primary impact by mollusks in the public and social welfare sector, the Southeast by insects in the forestry sector, the Midwest by plants in the agricultural sector, the West and Southwest by insects in the agricultural and public and social welfare sectors, respectively, and the outlying territories by insects in the public and social welfare sector (Fig. 3).

Six of the ten species with the highest reported, observed costs were insects, and nine of the ten species were animals, with Dutch elm fungus (Ophiostoma ulmi) the only exception (Table S4). Costs identifiable to specific species made up $\$ 326.49$ billion, with most reported costs being contributed by multiple or unspecified species (Fig. 3). We also identified regional differences in cost contributing species, such that there was little overlap in species with the greatest reported costs from region to region (Table 2), though across regions, animals were the dominant species ( 12 vs. 3 species, respectively). Only the feral pig and red imported fire ant appeared in the top 3 most expensive species in more than one of the region-specific species lists.

\subsection{Costs over time}

The recorded total cost of $\$ 1.22$ trillion between 1960 and 2020 (Fig. S1) amounted to an average annual cost over the entire period of $\$ 19.94$ billion per year. This cost increased from $\$ 2.0$ billion per year between 1960 and 1969 to $\$ 21.08$ billion per year between 2010 and 2020 (Fig. S1). Models differed in their predictions of invasive species costs borne by the United States economy over the 1960-2020 period (Fig. 4; Table S5). The GAM predicted costs of $\$ 4.01$ billion in 2020 , while robust regression predicted 2020 costs at $\$ 6.19$ billion (linear) and $\$ 0.28$ billion (quadratic). The latter projected decreasing costs in 


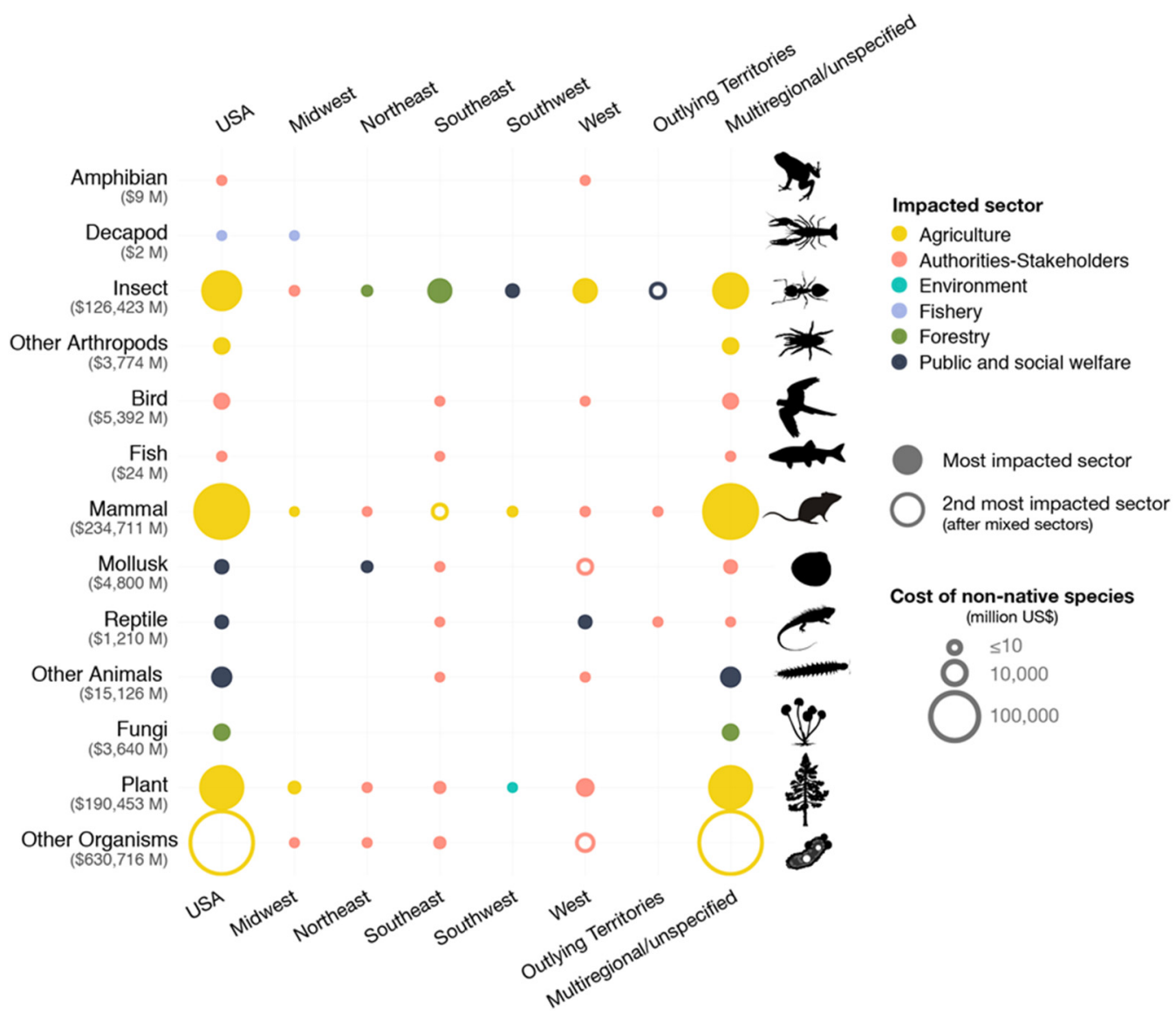

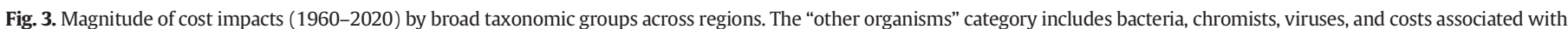

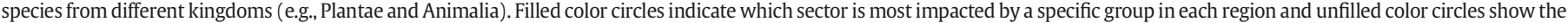

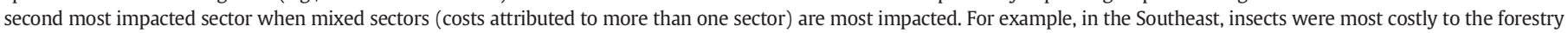
sector, while mammal costs were the highest for mixed sectors and second highest for agriculture.

recent years, which may be caused by a sensitivity to time lags in reporting, and it also had a relatively poor fit to the data (Table S5). The RMSE between the GAM and linear model was competitive $(\triangle \mathrm{RMSE}=0.02)$ (Table S5) and error bounds were large, reflecting high cost variance in recent years, which favored the use of robust regression over ordinary least squares regression. The estimate provided by quantile regression ranged over orders of magnitude, with the $0.1 \mathrm{st}$ quantile at $\$ 0.54$ billion, the 0.5 th quantile at $\$ 3.97$ billion, and 0.9 th quantile at $\$ 107.32$ billion in 2020. The MARS model provided the lowest RMSE (Table S5), however it exhibited high sensitivity to recent results, creating an apparently spurious decrease in recent costs. In fact, although both the more flexible non-linear models (MARS and quadratic robust regression) had different RMSE, this was driven by under-reported costs in recent years. For these models, predicted current costs fell below the overall annual average due to extremely high variance in recent costs and the occurrence of the three highest assigned costs in the 2000s, a probable artifact of the incompleteness of recent costs due to time lags in reporting.

\section{Discussion}

Biological invasions have cumulatively caused at least \$1.22 trillion in observed, highly reliable economic losses in the United States over the past six decades, with the largest impacts coming from mammalian, plant, and insect invaders. Agriculture suffered the highest costs, reflecting this sector's high susceptibility to economic damage from non-native species (Paini et al., 2016). The predominance of terrestrial systems in reported economic costs is surprising given the importance of aquatic systems for ecosystem services and livelihoods (Darwall et al., 2018), but may follow the large damages to agriculture and could reflect the wider focus within ecology towards terrestrial ecosystems (Menge et al., 2009; Cuthbert et al., 2021) and a relative lack of economic assets in aquatic realms. The fact that over two-thirds of observed costs were damages and losses is significant given these costs are harder to observe at large scales and more likely than management costs to be classified as potential (and thereby excluded from this analysis in the interest of conservatism). This indicates there may be considerable gains to be made from increased spending on biosecurity and post-invasion management. For example, the United States Department of Interior reported spending only \$143 million to manage invasive species in fiscal year 2020 (United States Department of the Interior, 2021 ), despite managing approximately $21 \%$ of the area of the United States (United States Department of the Interior, 2019). Of the money spent on management, only $\$ 1.35$ billion (3\% of $\$ 46.54$ billion) is spent on pre-invasion biosecurity, despite work highlighting the costeffectiveness of biosecurity protocols over longer-term management strategies (Leung et al., 2002; Lodge et al., 2006; Ahmed et al., 2021). Future investments in preventative measures and surveillance could help to offset future control and eradication costs in the United States and make those expenditures more effective in reducing damage and loss.

Costs from invasions appear to have unequal regional distribution, with the West reporting the greatest region-specific economic impacts and the Northeast the least. It is unclear whether the region-specific impacts in the West represent a distinct set of damaging species, better cost reporting, or a combination of the two. We observe that individual 

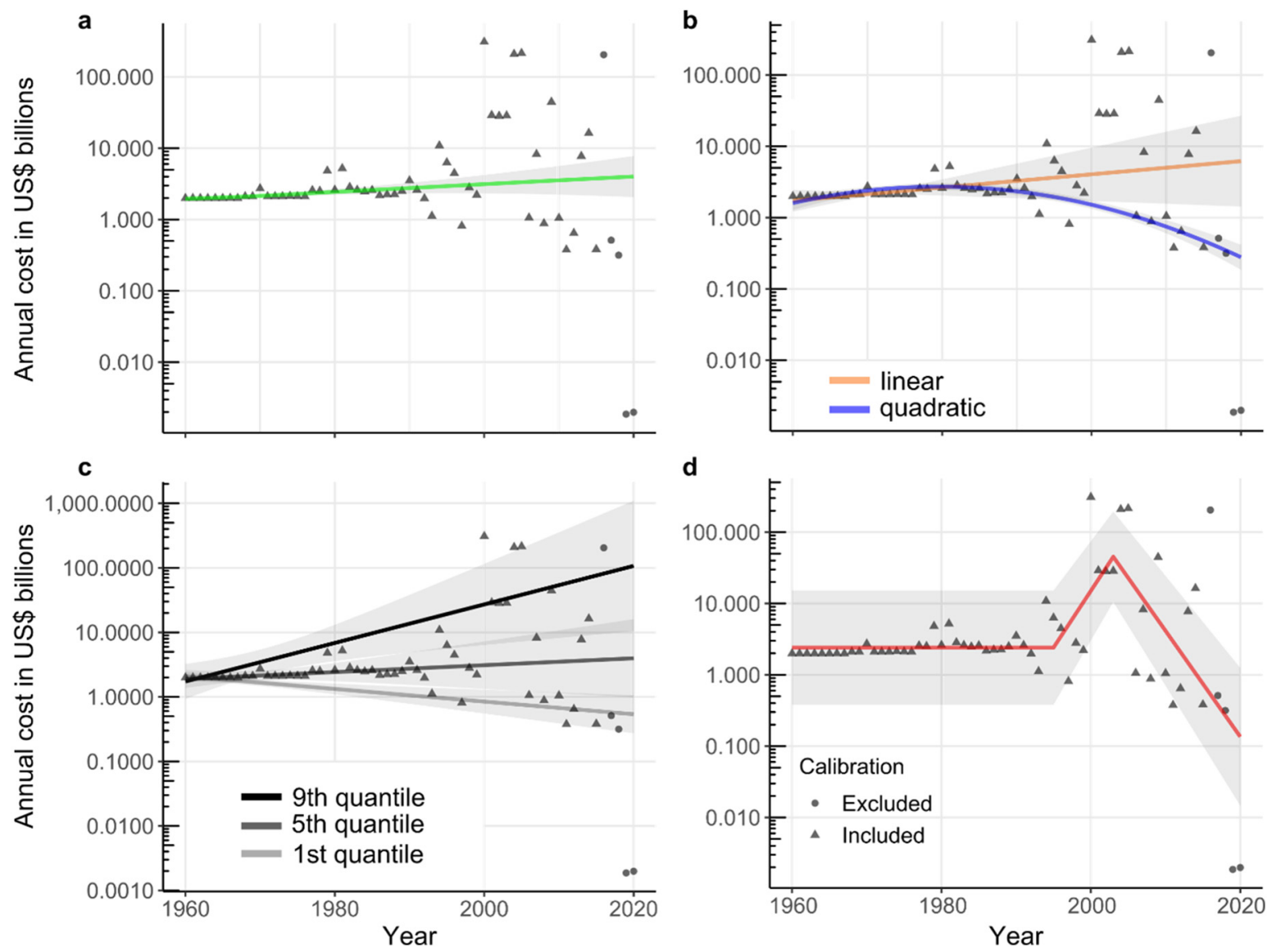

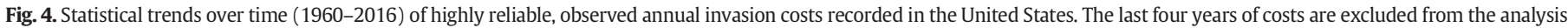

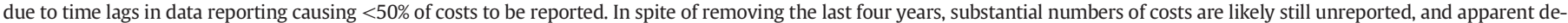

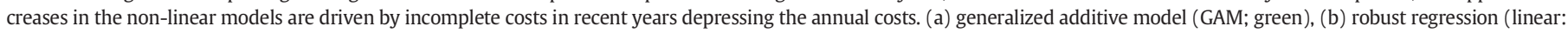

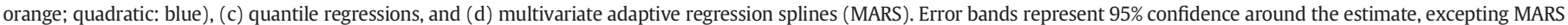
which are prediction intervals.

regions exhibited distinct patterning in costliest taxa and impacted sectors, potentially representing disparate cost reporting at the national scale, or differences in invasion patterns, introduction pathways and economic or environmental contexts. Notably, the costliest species USwide did not appear as the costliest species within regions, indicating the species with greatest impact nationwide may not be the same as those within a region. While the region-specific costs provide important insight into how risks and costs differ amongst regions, most economic costs lacked the spatial resolution necessary to be attributed to a specific state or region. We think that efforts to improve resolution and standardization of cost reporting would provide a clearer picture of overall costs and allow for more efficient mobilization of funding at relevant spatial scales.

Nationally and regionally, reported invasion costs were dominated by animals. Terrestrial animals, particularly mammals and insects, include some of the most notorious invasive species, and the large reported costs are a combination of substantial damages, management costs, and study effort associated with these species. For example, the two mammal species with the largest reported costs are feral cats and black rats, which inspire extensive research effort due to their ecological impacts (Loss et al., 2012; Knowlton et al., 2007), often close proximity with human populations, and the fact that both species inspire strong feelings, if for different reasons (Bjerke and Østdahl, 2004; Hall et al., 2016; Jarić et al., 2020). At the same time, insects caused considerable damage to United States forestry, agriculture, and health sectors, as has been shown to be the case globally (Bradshaw et al., 2016). Climate change may exacerbate such costs; in particular, it has been shown that it could lead to an average increase of $18 \%$ in areas suitable for global arthropod invaders (Bellard et al., 2013). While our findings match some other studies (e.g., Pimentel et al., 2000, 2005; Bradshaw et al., 2016) in terms of costliest taxa, this may not hold true in terms of ecological impact. In fact, the three most frequently studied invasive species, in terms of ecological impacts in the United States, were red swamp crayfish (Procambarus clarkii), the red imported fire ant, and Amur Honeysuckle (Lonicera maackii; Crystal-Ornelas and Lockwood, 2020). However, robust estimates of economic costs are only available for red imported fire ant (e.g., Lard et al., 2001). Further, due to a lack of published reports of their economic impacts, many well-known aquatic invaders such as the six problematic Asian carp species (Family Cyprinidae), northern snakehead (Channa argus), and rusty crayfish (Orconectes rusticus) had few, if any, cost estimates in our database. Though it is reasonable to assume that well-studied species also have significant economic impact, it should be noted that even poorly studied species may have similar effects and the majority of invasive species lack economic cost appraisals at national scales (e.g., Gren et al., 2009).

Our estimate of annual costs due to invasive species in the United States is lower than the $\$ 120-138$ billion annually often cited from earlier studies (Pimentel et al., 2000, 2005), but our approach and methods make this estimate more comprehensive and detailed. For example, our focus on highly reliable, observed costs enables costs to be assigned to specific time periods, in contrast to unspecified time frames in the Pimentel papers (Pimentel et al., 2000, 2005). Our discrete time frame allowed us to explicitly examine and synthesize cost trajectories over 
Table 2

Top 3 species with highest reported costs per region in the United States. Numbers of associated database entries are included.

\begin{tabular}{|c|c|c|c|c|c|}
\hline Region & Rank & Species & Common name & Cost ( $\$$ billion $)$ & Database entries \\
\hline \multirow[t]{3}{*}{ Northeast } & 1 & Lymantria dispar & Gypsy moth & 0.23 & 3 \\
\hline & 2 & Teredo navalis & Naval shipworm & 0.17 & 1 \\
\hline & 3 & Dreissena polymorpha & Zebra mussel & 0.14 & 6 \\
\hline \multirow[t]{3}{*}{ Southeast } & 1 & Sus scrofa & Feral pig & 0.46 & 30 \\
\hline & 2 & Xanthomonas axonopodis pv. citri & Citrus canker & 0.42 & 3 \\
\hline & 3 & Solenopsis invicta & Red imported fire ant & 0.33 & 5 \\
\hline \multirow[t]{3}{*}{ Midwest } & 1 & Euphorbia esula & Leafy spurge & 1.03 & 31 \\
\hline & 2 & Aphis glycines & Soybean aphid & 0.06 & 3 \\
\hline & 3 & Anoplophora glabripennis & Asian long-horned beetle & 0.01 & 11 \\
\hline \multirow[t]{3}{*}{ West } & 1 & Wasmannia auropunctata & Little fire ant & 7.31 & 27 \\
\hline & 2 & Apis mellifera & Africanized honeybee & 5.63 & 2 \\
\hline & 3 & Xylella fastidiosa & Leaf scorch bacteria & 1.40 & 29 \\
\hline \multirow[t]{3}{*}{ Southwest } & 1 & Solenopsis invicta & Red imported fire ant & 1.44 & 21 \\
\hline & 2 & Cochliomyia hominivorax & New World screw-worm fly & 0.52 & 1 \\
\hline & 3 & Sus scrofa & Feral pig & 0.10 & 1 \\
\hline \multirow[t]{3}{*}{ Outlying territories } & 1 & Aedes aegypti & Yellow fever mosquito & 1.00 & 39 \\
\hline & 2 & Boiga irregularis & Brown tree snake & 0.01 & 12 \\
\hline & 3 & Anoplolepis gracilipes & Yellow crazy ant & 0.01 & 11 \\
\hline
\end{tabular}

time, which has not been possible previously due to a lack of clearly reported temporal information. As a result, we have used the best available data to determine a lower floor for the reported costs of invasive species in the United States. Moreover, InvaCost data are categorized across an extensive range of descriptor variables $(>60)$ that allows compilation and comparison amongst these various descriptors. This database is also an Open-Source resource and will be updated as future costs are reported, increasing both the data accessibility and the transparency and currency of cost calculations. When we include potential and lower reliability cost entries in our calculations, the total cost increases to $\$ 4.52$ trillion, or $\$ 74.10$ billion annually, while still relying on costs assigned to defined time periods. Additionally, there are several reasons why our calculated costs are likely substantial underestimates, particularly in recent years, where extremely high variance limits confidence in the estimate of an annual average cost. Much of this variance results from two countervailing forces in the data. First, when reports failed to define the actual time period over which costs result, we conservatively assigned these costs to a single year (see Methods, Diagne et al., 2020a), potentially inflating costs in some years and likely underestimating them in other years. Related complications in accurately calculating costs arise from the difficulty of extrapolating costs over the full period of species impacts. Second, pervasive time lags between cost occurrences and their reporting reduced costs in recent years, and we had limited ability to accurately correct for this, other than as we did, by omitting the most recent, and probably amongst the costliest, four years. Additionally, if economic impacts of invasions follow time lag patterns similar to ecological impacts (Essl et al., 2011), the true economic costs of current invasions may take decades to manifest.

Further complicating the problem of estimating the true costs of invasion, temporal gaps in cost reporting preceding 1960 also render our cost estimates conservative. Specifically, as we constrained our analyses to costs reported post-1960, there are potentially large gaps in invasion costs incurred before this time. While invasions have been occurring at a substantially higher rate in recent decades (Seebens et al., 2017), invasions to the United States which occurred centuries ago (e.g., black rats) likely accrued costs that were not recorded in the database. This constrained temporal period of impacted years therefore does not fully account for temporal variations in potentially impacted sectors, ecosystem (dis)services and cultural values that can arise (i.e., over centuries) due to invasion. Equally, while a lack of data may not equate to a lack of cost, we do not expect all known invaders in the United States to have tangible economic impact. However, these impacts may emerge over time with changes to activity sectors and societal values. We also note that some invasions can also have stark economic benefits, for example, through recreational fisheries targeting non-native species or non-native plants cultivated for agriculture and horticulture; such species require special consideration in management strategies and estimation of impacts.

Additional missing costs result from the inherent difficulty in estimating economic losses in relation to ecosystem services (Nunes and van den Bergh, 2001; but see Hanley and Roberts, 2019). In many cases these costs are accrued across many stakeholders and in an indirectly realized way. For example, loss of water clarity may be worth $\$ 140$ million to local citizens despite no (or very few) individuals realizing direct financial loss (Walsh et al., 2016). While these non-markettype costs are not captured in our current analysis if not monetarily valued, the $\$ 102.46$ billion in damage/losses found in the environmental sector may serve as an indicator of these sorts of losses. Underestimation also stems from gaps in accounting of both the known and unknown damage caused by some taxonomic groups and impacted habitat types. Furthermore, non-market costs (e.g., nutrient cycling, water filtration, etc.) are rarely assigned value and can be substantially higher than market costs (Holmes et al., 2009). Finally, economic impacts for most invasive species have simply not been estimated (Gren et al., 2009; Cuthbert et al., 2021), which may reflect broader biases in ecological impact research across habitats and geographic regions (Crystal-Ornelas and Lockwood, 2020). Such biases may explain why costs of terrestrial invaders were greater than aquatic invaders, despite the often-cited impacts of the latter (Ricciardi and Macisaac, 2011). Given the missing and biased costs, the figures presented here should not be considered as static, final amounts but rather as the most current and inclusive estimate of the minimum costs of invasions in the United States thus far. Indeed, these outcomes are the results of analyses of a database that is expected and intended to evolve over time, and which will offer unique opportunities to improve and refine cost information (Diagne et al., 2020b).

In the past six decades, United States invasion costs have apparently increased as a result of both increasing invasion rates and spread of extant invasions. Although a couple of our models exhibit declining trends in invasive costs, these models appear to be spuriously leveraged by missing data in the most recent and, likely, costliest years. Of course, for some specific taxonomic groups and habitat types, invasion costs may indeed be falling due to improvements in pre-invasion controls and post-invasion management efficiency. For example, Great Lakes' invasion rates have declined in recent years due to improvements in regulations targeting ship ballast water (i.e., ballast water exchange and ballast water treatment implementation) (Sturtevant et al., 2019). Nonetheless, we believe that the models illustrating increasing costs over time are the most probable. In that regard, the GAM and linear 
robust regression, which were less sensitive to outliers, predicted reported invasion costs in 2020 to be at least $\$ 4.01$ and $\$ 6.19$ billion, respectively. Indeed, across the globe, invasion rates show no signs of saturation (Seebens et al., 2017). In the future, as global trade increases and climate change patterns continue to intensify (Bellard et al., 2013; Seebens et al., 2018), we anticipate a further increase in invasion costs, particularly if investments in biosecurity remain insufficient to prevent future introductions (Leung et al., 2002). Given these increasing numbers and the lack of cost information we have for most invaders, our findings provide critical information for managers, planners, and policymakers.

Finally, our study highlighted tremendous but still largely underestimated costs of invaders in the United States. It is worth noting that the cost figures presented here only reflect a snapshot of the data currently available. As a result, we urge increased and improved (i.e., standardized, Diagne et al., 2020a) cost reporting by stakeholders and managers in the context of biological invasions. We stress that a lack of reported economic impact does not imply a similar lack of incurred ecological impact from invasive populations, with wellreported reductions in fitness, abundance, and diversity of native species as a result of biological invasion (Pyšek et al., 2020). Whereas economic rationale should not be a requirement to address ecosystem degradation, burgeoning costs synthesized in this study should further motivate policy action to reduce all effects of biological invasions. Indeed, biological invaders are also tremendous, yet often unquantifiable threats for biodiversity, ecological functioning, and human health (Kumschick et al., 2015; Ogden et al., 2019; IPBES, 2019; Pyšek et al., 2020). While not a complete estimate of the true costs of invasions, economics is an integral component in understanding invasion processes, impacts, and decision-making (Epanchin-Niell, 2017). The data gaps notwithstanding, an integrated data collection point, such as the InvaCost database, is an important first step in offering future decision-makers a comprehensive approach to report and utilize estimates of economic costs. Moreover, we consider our work as a basis for improving further research on the topic. Indeed, future studies should seek to rectify existing knowledge gaps in economic costs across spatial, taxonomic, geographic, and environmental scales, in the United States and beyond (see Diagne et al., 2020b for a comprehensive list of ideas and recommendations). For instance, future research should strive to scale cost impacts by the impacted surface to allow large-scale comparisons or extrapolations of the cost amounts. Furthermore, increased investments in biosecurity to reduce arrival and secondary spread of non-natives are urgently needed if costs are to be contained. Given that proactive management can be magnitudes more cost-effective than ongoing damages (Leung et al., 2002; Ahmed et al., 2021), monitoring, biosecurity and control investments should be prioritized to offset future costs and societal disruptions from invasions. Ultimately, our work provides an urgent warning on the massive, expanding costs of invasive species across the United States that if left unchecked will continue unabated.

Supplementary data to this article can be found online at https://doi. org/10.1016/j.scitotenv.2021.151318.

\section{Funding}

The authors acknowledge the French National Research Agency (ANR-14-CE02-0021) and the BNP-Paribas Foundation Climate Initiative for funding the Invacost project that allowed the construction of the InvaCost database. The present work was conducted following a workshop funded by the AXA Research Fund Chair of Invasion Biology. It is part of, and $C D$ was funded by, the Alien Scenarios project of the BiodivERsA-Belmont Forum 2018 on biodiversity scenarios (BMBF/PT DLR 01LC1807C). Furthermore, JFL would like to thank the Auburn University School of Forestry and Wildlife Sciences for travel support to attend the Invacost workshop. RNC acknowledges funding from the Alexander von Humboldt Foundation.

\section{CRediT authorship contribution statement}

Jean E. Fantle-Lepczyk: Conceptualization, Methodology, Formal analysis, Investigation, Data curation, Writing - original draft, Writing review \& editing, Project administration. Phillip J. Haubrock: Conceptualization, Methodology, Software, Formal analysis, Investigation, Writing - original draft, Writing - review \& editing, Visualization. Andrew M. Kramer: Conceptualization, Methodology, Software, Formal analysis, Investigation, Data curation, Writing - original draft, Writing review \& editing. Ross N. Cuthbert: Conceptualization, Methodology, Software, Formal analysis, Investigation, Writing - original draft, Writing - review \& editing. Anna J. Turbelin: Software, Formal analysis, Writing - review \& editing, Visualization. Robert Crystal-Ornelas: Formal analysis, Writing - review \& editing. Christophe Diagne: Conceptualization, Methodology, Formal analysis, Resources, Writing - review \& editing. Franck Courchamp: Conceptualization, Methodology, Resources, Writing - review \& editing, Funding acquisition, Project administration.

\section{Declaration of competing interest}

The authors declare that they have no known competing financial interests or personal relationships that could have appeared to influence the work reported in this paper.

\section{Acknowledgments}

The authors wish to thank all InvaCost workshop attendees and project participants who contributed to the development of the InvaCost database, as well as the two anonymous reviewers whose comments helped improve the manuscript.

\section{References}

Ahmed, D.A., Hudgins, E.J., Cuthbert, R.N., Kourantidou, M., Diagne, C., Haubrock, P.J. Leung, B., Liu, C., Leroy, B., Petrovskii, S., Courchamp, F., 2021. Managing biological invasions: the cost of inaction. https://doi.org/10.21203/rs.3.rs-300416/v1 ResearchSquare (pre-print).

Anderson, A., Slootmaker, C., Harper, E., Holderieath, J., Shwiff, S.A., 2016. Economic estimates of feral swine damage and control in 11 US states. Crop Prot. 89, 89-94.

Angulo, E., Diagne, C., Ballesteros-Mejia, L., Adamjy, T., Ahmed, D.A., Akulov, E., Banerjee, A.K., Capinha, C., Dia, C.A.K.M., Dobigny, G., Duboscq-Carra, V.G., Golivets, M., Haubrock, P.J., Heringer, G., Kirichenko, N., Kourantidouo, M., Liu, C., Nuñez, M.A., Renault, D., Roiz, D., Taheri, A., Verbrugge, L.N.H., Watari, Y., Xiong, W., Courchamp, F., 2021. Non-English languages enrich scientific data: the example of the costs of biological invasions. Sci. Total Environ. 775, 144441.

Aukema, J.E., Leung, B., Kovacs, K., Chivers, C., Britton, K.O., Englin, J., Frankel, S.J., Haight, R.G., Holmes, T.P., Liebhold, A.M., McCullough, D.G., Von Holle, B., 2011. Economic impacts of non-native forest insects in the continental United States. PLoS ONE 6, e24587.

Bellard, C., Thuiller, W., Leroy, B., Genovesi, P., Bakkenes, M., Courchamp, F., 2013. Will climate change promote future invasions? $19,3740-3748$.

Bjerke, T., Østdahl, T., 2004. Animal-related attitudes and activities in an urban population. Anthrozoös 17, 109-129.

Blackburn, T.M., Bellard, C., Ricciardi, A., 2019. Alien versus native species as drivers of recent extinctions. Front. Ecol. Environ. 17, 203-207.

Boelman, S.F., Neilson, F.M., Dardeau Jr., E.A., Cross, T., 1997. Zebra Mussel (Dreissena polymorpha) Control Handbook for Facility Operators. U.S. Army Engineer Waterways Experiment Station, Vicksburg, MS Misc. Paper EL-97-1.

Bradshaw, C.A., Leroy, B., Bellard, C., Roiz, D., Albert, C., Fournier, A., Barbet-Massin, M., Salles, J.M., Simard, F., Courchamp, F., 2016. Massive yet grossly underestimated global costs of invasive insects. Nat. Commun. 7, 12986.

Connelly, N.A., O’Neill, C.R., Knuth, B.A., Brown, T.L., 2007. Economic impacts of zebra mussels on drinking water treatment and electric power generation facilities. Environ. Manag. 40, 105-112.

Crystal-Ornelas, R., Lockwood, J.L., 2020. The 'known unknowns' of invasive species impact measurement and the quest for comprehensive impact frameworks. Biol. Invasions 22, 1513-1525.

Cuthbert, R.N., Bacher, S., Blackburn, T.M., Briski, E., Diagne, C., Dick, J.T.A., Essl, F. Genovesi, P., Haubrock, P.J., Latombe, G., Lenzner, B., Meinard, Y., Pauchard, A., Pyšek, P., Ricciardi, A., Richardson, D.M., Russell, J.C., Simberloff, D., Courchamp, F., 2020. Invasion costs, impacts, and human agency: response to sagoff 2019. Conserv. Biol. 34, 1579-1582.

Cuthbert, R.N., Pattison, Z., Taylor, N.G., Verbrugge, L., Diagne, C., Ahmed, D.A., Leroy, B., Angulo, E., Briski, E., Capinha, C., Catford, J.A., Dalu, T., Essl, F., Gozlan, R.E., Haubrock, P.J., Kourantidou, M., Kramer, A.M., Renault, D., Wasserman, R.J., 
Courchamp, F., 2021. Global economic costs of aquatic invasive alien species. Sci. Total Environ. 775, 145238.

Darwall, W., Bremerich, V., De Wever, A., Dell, A.I., Freyhof, J., Gessner, M.O., Grossart, H.P., Harrison, I., Irvine, K., Jähnig, S.C., Jeschke, J.M., Lee, J.J., Lu, C., Lewandowska, A.M., Monaghan, M.T., Nejstgaard, J.C., Patricio, H., Schmidt-Kloiber, A., Stuart, S.N., Thieme, M., Tockner, K., Turak, E., Weyl, O., 2018. The alliance for freshwater life: a global call to unite efforts for freshwater biodiversity science and conservation. Aquat. Conserv. 28, 1015-1022.

Diagne, C., Leroy, B., Gozlan, R.E., Vaissière, A.C., Assailly, C., Nuninger, L., Roiz, D., Jourdain, F., Jarić, I., Courchamp, F., 2020a. InvaCost, a public database of the economic costs of biological invasions worldwide. Sci. Data 7,1-12.

Diagne, C., Catford, J.A., Essl, F., Nuñez, M.A., Courchamp, F., 2020b. What are the economic costs of biological invasions? A complex topic requiring international and interdisciplinary expertise. $63,5-37$.

Diagne, C., Leroy, B., Vaissière, A.C., Gozlan, R.E., Roiz, D., Jarić, I., Salles, J.-M., Bradshaw, C.J.A., Courchamp, F., 2021. High and rising economic costs of biological invasions worldwide. Nature 592, 571-576.

Doherty, T.S., Glen, A.S., Nimmod, D.G., Ritchiea, E.G., Dickman, C.R., 2016. Invasive predators and global biodiversity loss. Proc. Natl. Acad. Sci. U. S. A. 113, 11261-11265.

Dorcas, M.E., Willson, J.D., Reed, R.N., Snow, R.W., Rochford, M.R., Miller, M.A., Meshaka Jr., W.E., Andreadis Jr., P.T., Mazzotti Jr., F.J., Romagosa Jr., C.M., Hart Jr., K.M., 2012. Severe mammal declines coincide with proliferation of invasive Burmese pythons in Everglades National Park. Proc. Natl. Acad. Sci. U.S.A. 109, 2418-2422.

Dueñas, M., Ruffhead, H.J., Wakefield, N.H., Roberts, P.D., Hemming, D.J., Diaz-Soltero, H., 2018. The role played by invasive species in interactions with endangered and threatened species in the United States: a systematic review. 27, 3171-3183.

Epanchin-Niell, R.S., 2017. Economics of invasive species policy and management. Biol. Invasions $19,3333-3354$

Essl, F., Dullinger, S., Rabitsch, W., Hulme, P.E., Hülber, K., Jarošík, V., Kleinbauer, I., Krausmann, F., Kühn, I., Nentwig, W., Vilà, M., 2011. Socioeconomic legacy yields an invasion debt. Proc. Natl. Acad. Sci. U. S. A. 108, 203-207.

Gren, M., Isacs, L., Carlsson, M., 2009. Costs of alien invasive species in Sweden. Ambio 38, $135-140$.

Hall, C.M., Adams, N.A., Bradley, J.S., Bryant, K.A., Davis, A.A., Dickman, C.R., Fujita, T., Kobayashi, S., Lepczyk, C.A., McBride, E.A., Pollock, K.H., Styles, I.M., van Heezik, Y., Wang, F., Calver, M.C., 2016. Community attitudes and practices of urban residents regarding predation by pet cats on wildlife: an international comparison. PLoS ONE 11, e0151962.

Hanley, N., Roberts, M., 2019. The economic benefits of invasive species management. 1, 124-137.

Hoffmann, B.D., Broadhurst, L.M., 2016. The economic cost of managing invasive species in Australia. NeoBiota 31, 1-18.

Holmes, T.P., Aukema, J.E., Von Holle, B., Liebhold, A., Sills, E., 2009. Economic impacts of invasive species in forests past, present, and future. Year in Ecol and Conserv Biol. 1162, pp. 18-38 2009.

IPBES, 2019. In: Brondizio, E.S., Settele, J., Díaz, S., Ngo, H.T. (Eds.), Global Assessment Report on Biodiversity and Ecosystem Services of the Intergovernmental Science-Policy Platform on Biodiversity and Ecosystem Services. IPBES secretariat, Bonn, Germany.

Jarić, I., Courchamp, F., Correia, R.A., Crowley, S.L., Essl, F., Fischer, A., González-Moreno, P., Kalinkat, G., Lambin, X., Lenzner, B., Meinard, Y., Mill, A., Musseau, C., Novoa, A., Pergl, J., Pyšek, P., Pyšková, K., Robertson, P., von Schmalensee, M., Stefansson, R.A., Jeschke, J.M., 2020. The role of species charisma in biological invasions. Front. Ecol. Environ. $18,345-353$.

Johnson, M., Meder, M.E., 2013. Effects of Aquatic Invasive Species on Home Prices: Evidence From Wisconsin. http://wwwaquaticnuisanceorg/wordpress/wp-content/ uploads/2010/06/Effects-of-Aquatic-Invasive-Species-on-Home-Prices-Evidencefrom-Wisconsin-Johnson-and-Meder-2013pdf/. (Accessed 28 August 2020).

Knowlton, J.L., Donlan, C.J., Roemer, G.W., Samaniego-Harrera, A., Keit, B.S., Aguire-Munoz, A.A., Faulkner, K.R., Tershy, B.R., 2007. Non-native Mammal Eradications and the Status of Insular Mammals on the California Channel Islands, USA and Pacific Baja California Islands, Mexico. 52. Southwest Nat, pp. 528-540.

Kovacs, K.F., Haight, R.G., McCullough, D.G., Mercader, R.J., Siegert, N.W., Liebhold, A.M., 2010. Cost of potential emerald ash borer damage in US communities, 2009-2019. Ecol. Econ. 69, 569-578.

Kumschick, S., Gaertner, M., Vila, M., Essl, F., Jeschke, J.M., Pyšek, P., Ricciardi, A., Bacher, S., Blackburn, T.M., Dick, J.T.A., Evans, T., Hulme, P.E., Kühn, I., Mrugała, A., Pergl, J., Rabitsch, W., Richardson, D.M., Sendek, A., Winter, M., 2015. Ecological impacts of alien species: quantification, scope, caveats, and recommendations. Bioscience 65 , 55-63.

Lard, C.F., Salin, V., Willis, D.B., Robison, S., Hadley, J., Schroeder, K., 2001. The Statewide Economic Impact of Red Imported Fire Ants in Texas: A Part of the Texas Fire Ant Initiative 1999-2001 Fire Ant Economic Research Report \#01-08. Texas A\&M University, College Station, TX

Leroy, B., Kramer, A., Vaissière, A., Courchamp, F., Diagne, C., 2021. Analysing global economic costs of invasive alien species with the invacost $\mathrm{R}$ package. bioRxiv. https:// www.biorxiv.org/content/10.1101/2020.12.10.419432v1.

Leung, B., Lodge, D.M., Finnoff, D., Shogren, J.F., Lewis, M.A., Lamberti, G., 2002. An ounce of prevention or a pound of cure: bioeconomic risk analysis of invasive species. Proc. Biol. Sci. 269, 2407-2413.
Lockwood, J.L., Welbourne, D.J., Romagosa, C.M., Cassey, P., Mandrak, N.E., Strecker, A Leung, B., Stringham, O.C., Udell, B., Episcopio-Sturgeon, D.J., Tlusty, M.F., 2019. When pets become pests: the role of the exotic pet trade in producing invasive vertebrate animals. Front. Ecol. Environ. 17, 323-330.

Lodge, D.M., Williams, S., MacIsaac, H.J., Hayes, K.R., Leung, B., Reichard, S., Mack, R.N., Moyle, P.B., Smith, M., Andow, D.A., Carlton, J.T., McMichael, A., 2006. Biological invasions: recommendations for US policy and management. Ecol. Appl. 16, 2035-2054.

Lohr, C., Cox, L.J., Lepczyk, C.A., 2013. Costs and benefits of trap-neuter-release and euthanasia for removal of urban cats in Oahu,Hawaii. 27, 64-73.

Loss, S.R., Will, T., Marra, P.P., 2012. The impact of free-ranging domestic cats on wildlife of the United States. Nat. Commun. 4, 1396.

Martin, L.J., Blossey, B., 2013. The runaway weed: costs and failures of Phragmites australis management in the USA. 36, 626-632.

Mcmanus, M., Csóka, G., 2007. History and impact of gypsy moth in North America and comparison to the recent outbreaks in Europe. 3, 47-64.

Mefford, C., Cohen, S., Sampath, S., Haring, D., Jellicoe, M., Nally, K., Streamer, A., Viola, E., 2017. Economic impact of invasive species: direct costs estimates and economic impacts for Washington state. https://invasivespecieswagov/council_projects/ economic_impact/Invasive\%20Species\%20Economic\%20Impacts\%20Report\%20J an2017pdf/. (Accessed 28 August 2020).

Menge, B.A., Chan, F., Dudas, S., Eerkes-Medrano, D., Grorud-Colvert, K., Heiman, K. Hessing-Lewis, M., Iles, A., Milston-Clements, R., Noble, M., Page-Albins, K., Richmond, E., Rilov, G., Rose, J., Tyburczy, J., Vinueza, L., Zarnetske, P., 2009. Terrestria ecologists ignore aquatic literature: asymmetry in citation breadth in ecological publications and implications for generality and progress in ecology. J. Exp. Mar. Biol. Ecol. 377, 93-100.

Miehls, A., Mason, D.M., Frank, K.A., Krause, A.E., Peacor, S.D., Taylor, W.W., 2009. Invasive species impacts on ecosystem structure and function: a comparison of Oneida Lake, New York, USA, before and after zebra mussel invasion. Ecol. Model. 220, 3194-3209.

Nunes, P.A.L.D., van den Bergh, J.C.J.M., 2001. Economic valuation of biodiversity: sense or nonsense? Ecol. Econ. 39, 203-222.

Office of the United States Trade Representative, 2020. Trade Partners-Countries and Regions. https://ustrgov/countries-regions\#: :text=The\%20United\%20States\%20has\% 20trade,75\%20countries\%20around\%20the\%20world. (Accessed 8 January 2020).

Ogden, N.H., Wilson, J.R., Richardson, D.M., Hui, C., Davies, S.J., Kumschick, S., Le Roux, J.J. Measey, J., Saul, W.-C., Pulliam, J.R.C., 2019. Emerging infectious diseases and biological invasions: a call for a One Health collaboration in science and management R. 6, 181577.

Paini, D.R., Sheppard, A.W., Cook, D.C., De Barro, P.J., Worner, S.P., Thomas, M.B., 2016. Global threat to agriculture from invasive species. Proc. Natl. Acad. Sci. U. S. A. 113, 7575-7579.

Pimentel, D., Lach, L., Zuniga, R., Morrison, D., 2000. Environmental and economic costs of nonindigenous species in the United States. Bioscience 50, 53-56.

Pimentel, D., Zuniga, R., Morrison, D., 2005. Update of the environmental and economic costs associated with alien invasive species in the United States. Ecol. Econ. 52, 273-288.

Pyšek, P., Hulme, P.E., Simberloff, D., Bacher, S., Blackburn, T.M., Carlton, J.T., Dawson, W., Essl, F., Foxcroft, L.C., Genovesi, P., 2020. Scientists' warning on invasive alien species. Biol. Rev. 95, 1511-1534.

R Core Team, 2020. R: A Language and Environment for Statistical Computing. R Foundation for Statistical Computing, Vienna, Austria. http://wwwR-projectorg/.

Ricciardi, A., Macisaac, H.J., 2011. Impacts of biological invasions on freshwater ecosystems. In: Richardson, D.M. (Ed.), 50 Years of Invasion Ecology. Wiley-Blackwell, Oxford, UK, pp. 211-224.

Seebens, H., et al., 2017. No saturation in the accumulation of alien species worldwide. Nat. Commun. 8, 14435

Seebens, H., et al., 2018. Global rise in emerging alien species results from increased accessibility of new source pools. Proc. Natl. Acad. Sci. U. S. A. 115, e2264-e2273.

Shepard, D.S., Coudeville, L., Halasa, Y.A., Zambrano, B., Dayan, G.H., 2011. Economic impact of dengue illness in the Americas. 84, 200-207.

Simberloff, D., 2015. Non-native invasive species and novel ecosystems. F1000 Prime Rep $7,47$.

Sturtevant, R.A., Mason, D.M., Rutherford, E.S., Elgin, A., Lower, E., Martinez, F., 2019. Recent history of nonindigenous species in the Laurentian Great Lakes; an update to Mills et al., 1993 (25 years later). J. Great Lakes Res. 45, 1011-1035.

Sytsma, M., Rouhe, A.C., 2007. Feral Swine Action Plan for Oregon. Portland State University Center for Lakes and Reservoirs.

United States Department of the Interior, 2019. Office of Congressional and Legislative Affairs S434. https://wwwdoigov/ocl/s-434. (Accessed 22 September 2020).

United States Department of the Interior, 2021. U.S. Department of the Interior Invasive Species Strategic Plan, Fiscal Years 2021-2025 Washington, D.C., 54 pp.

Walsh, J.R., Carpenter, S.R., Vander Zanden, M.J., 2016. Invader triggers loss of ecosystem service. Proc. Natl. Acad. Sci. U. S. A. 113, 4081-4085.

Wiles, G.J., Bart, J., Beck, R.E., Aguon, C.F., 2003. Impacts of the brown tree snake: patterns of decline and species persistence in Guam's avifauna. Conserv. Biol. 17, 1350-1360.

World Bank, 2020. 2020 GDP (current \$) - United States. https://dataworldbankorg/ indicator/NYGDPMKTPCD?locations=US. (Accessed 8 January 2020).

Zavaleta, E., 2000. The economic value of controlling an invasive shrub. Ambio 29 $462-467$. 